\title{
Измерение оптических свойств металл-диэлектрических поверхностей с помощью терагерцовой поверхностно-плазмонной интерферометрии
}

\author{
В.В. Герасимов ${ }^{1,2}$, А.К. Никитин ${ }^{2,3}$, О.В. Хитров ${ }^{3}$, А.Г. Лемзяков ${ }^{1,2}$ \\ ${ }^{1}$ Институт ядерной физики им. Г.И.Будкера СО РАН, Новосибирск, \\ 630090, пр. Академика Лаврентьева, 11 \\ ${ }^{2}$ Новосибирский государственный университет, Новосибирск, 630090, Пирогова, 2 \\ ${ }^{3}$ Научно-технологический центр уникального приборостроения РАН, Москва, 117342, Бутлерова, 15 \\ тел:+7 (383) 329-48-39, эл. почта:v.v.gerasimov3@gmail.com
}

DOI $10.34077 /$ RCSP2021-65

Поверхностные плазмон-поляритоны (ППП) - это разновидность поверхностных $p$-поляризованных электромагнитных волн, распространяющихся вдоль границы металл-диэлектрик, неразрывно связанных с волной свободных зарядов на поверхности проводника. ППП в видимом и ближнем ИК диапазоне широко используются для спектроскопии тонких пленок на поверхности проводников и оценки качества обработки поверхности металла [1]. Это возможно благодаря высокой концентрации электромагнитного поля вблизи проводящей поверхности (как со стороны диэлектрика, та и со стороны проводника).

В терагерцовом (ТГц) диапазоне частот металлы имеют высокую проводимость, приближаясь к идеальным проводникам; в результате они слабо связаны с поверхностью металла и распространяются на десятки сантиметров. С одной стороны, это позволяет более проще, чем в видимом диапазоне частот, измерять длину распространения ППП вдоль поверхности (в видимом диапазона она составляет несколько микрометров), зная которую можно определить мнимую часть его показателя преломления $\kappa=\kappa^{\prime}+i \cdot \kappa^{\prime \prime}$. С другой стороны, из-за высокой проводимости металлов, реальная часть показателя преломления очень мало отличается от единицы ( $\approx 10^{-5}$ на чистом металле), что налагает высокие требования к точности измерений, трудно достигаемые существующими методами [2].

В данной работе представляются первые экспериментальные результаты по измерению реальной и мнимой частей показателя преломления ППП с помощью плазмонного интерферометра Майкельсона [3] с использованием монохроматического перестраиваемого терагерцового Новосибирского лазера на свободных электронах (ЛСЭ) [4]. Это стало возможным благодаря предшествующим экспериментальным исследованиям по генерации и распространению ППП, их отражению плоскими зеркалами, делению с помощью тонких диэлектрических пленок. В качестве образцов использовались полированные стеклянные пластины с непрозрачным золотым напылением, покрытые слоем $\mathrm{ZnS}$ толщиной от 90 до 1000 нм. Точность измерения реальной части показателя преломления ППП зависела от толщины диэлектрического покрытия и стабильности работы ЛСЭ, достигая $3 \cdot 10^{-4} \mathrm{RIU}$.

В работе использовалось оборудование ЦКП «СЦСТИ» на базе УНУ "Новосибирский ЛСЭ" в ИЯФ CO PAH.

\section{Лumepamypa}

[1] Agranovich V M and Mills D L 1982 Surface polaritons. Surface electromagnetic waves at surfaces and interfaces (Amsterdam: North Holland Publ. Company)

[2] Azarov, I.A., Shvets, V.A., Prokopiev, V.Y. et al. A terahertz ellipsometer. Instrum Exp Tech 58, 381388 (2015).

[3] A.K. Nikitin, O.V. Khitrov, V.V. Gerasimov, "Quality control of solid surfaces by the method of surface plasmon interferometry in the THz range", J. Physics: Conf. Series, vol. 1636, 012037, 2020.

[4] G. N. Kulipanov, et al, "Novosibirsk free electron laser facility description and recent experiments," IEEE Trans. Terahertz Sci. Technol. 5, 798-809 (2015). 